\title{
THE JUNE 1863 AND THE JULY 1880 EARTHQUAKES IN LUZON, PHILIPPINES: INTERPRETATIONS AND RESPONSES
}

\author{
Kerby Álvarez \\ Department of History, University of the Philippines Diliman-CSIC \\ alvarez.kerby@gmail.com
}

This paper presents a historical analysis of the response of the government and the people after the June 1863 and July 1880 earthquake disasters. It provides a discussion of the extent of damage caused by the two earthquakes, and the post-disaster responses of the Spanish civil government in Manila and the central government in Madrid. This study also narrates the varying interpretations of the earthquakes, from the point of view of the Church, and from the perspective of the scientific community.

The two earthquakes became profound catalysts for the changes that had taken place in its immediate aftermath. First, it prompted the civil government to initiate and implement a systematic disaster response plan and to institutionalize earthquake studies as a prerequisite in crafting seismic engineering and architectural plans for the communities. Second, what transpired after the two earthquakes revealed the long-standing problems in the bureaucracy and the need to implement modern and scientific approaches to urban planning and infrastructural integrity of the city. Ultimately, these catastrophic events paved the way for the institutionalization of scientific, architectural, and public engineering reforms in the colony.

KEYWORDS: Earthquakes, religious responses, Spanish bureaucracy, Jesuits, colonial engineers.

\section{LOS TERREMOTOS DE JUNIO DE 1863 Y JULIO DE 1880 EN LUZÓN, FILIPINAS: INTERPRETA- CIONES Y RESPUESTAS}

Este trabajo de investigación presenta un análisis histórico de la respuesta del gobierno y del pueblo después de los terremotos de junio de 1863 y julio de 1880. Proporciona una discusión sobre el alcance de los daños causados por los dos terremotos y las respuestas del gobier- 
no civil español en Manila y del gobierno central de Madrid después los desastres. Este estudio también relata las diversas interpretaciones de los terremotos, desde el punto de vista de la Iglesia, y desde la perspectiva de la comunidad científica.

Los dos terremotos se convirtieron en catalizadores de los cambios que tuvieron lugar inmediatamente después. En primer lugar, motivaron al gobierno civil a iniciar e implementar un plan sistemático de respuesta ante desastres e institucionalizar los estudios de terremotos como requisito previo en la elaboración de planes de ingeniería sísmica y arquitectura para las comunidades. En segundo lugar, los acontecimientos que sucedieron después de los terremotos, revelaron los problemas estructurales de la burocracia y la necesidad de implementar enfoques modernos y científicos para la planificación urbana y la integridad de la infraestructura de la ciudad. Finalmente, estas catástrofes allanaron el camino para la institucionalización de las reformas científicas, arquitectónicas y de ingeniería pública en la colonia.

PALABRAS ClAVE: Terremotos, respuestas religiosas, burocracia española, jesuitas, ingenieros coloniales.

\section{Introduction}

The world of the nineteenth century, in Spain and its colonies, was a period of volatile politics, as well as significant scientific and technological advancements. In the case of the Philippines, the archipelago was at the crossroads: on the one hand, it was a colony with a government always facing perennial fiscal imbalance, a territory in almost complete control of religious orders and an archipelago hampered by frequent calamities, and on the other hand, it was a site of burgeoning scientific advancements pertaining to the physical environments, instrumentation, and institutionalization of scientific disciplines, and the influx of foreign knowledge for the benefit of the trading sector. Huetz de Lemps describes this period as an era of massive urbanization, landscape change, and population growth, and the rise of complex socio-economic movements that made towns, such as the capital city Manila, experience major urban sprawls and transformation. ${ }^{1}$

Earthquakes as a Philippine life experience are not exclusively $19^{\text {th }}$ century phenomena. In the seismological compendium by Saderra Masó, he lists down 58 earthquakes in different parts of the archipelago from 1599-1862. ${ }^{2}$ From this historical record, it can be inferred the frequency and regularity in the occurrence of earthquakes. From this stand-

1. Huetz de Lemps, Xavier, «Materiales Ligeros vs. Materiales Fuertes: The Conflict between Nipa Huts and Stone Buildings in the $19^{\text {th }}$-century Manila», en Ordoñez, Elmer (ed.), The Philippine Revolution and Beyond, vol. 1, Manila, Philippine Centennial Commission, National Commission for Culture and the Arts, 1998, p. 160 .

2. Saderra Masó, Miguel, Catalogue of Violent and Destructive Earthquakes in the Philippines, 1599-1909, with an appendix of earthquakes in the Marianas, Manila, Bureau of Printing, 1910, pp. 7-16. 
point, the Spanish authorities in the Philippines needed to device urban engineering mechanisms in establishing towns and building infrastructures. Generally, from the $17^{\text {th }}$ to the late $18^{\text {th }}$ century, the presence of colonial professionals was lacking, and most of the «architects» of towns and its administrators were priests, military personnel, or local community leaders. Nineteenth-century Englishman Sir John Bowring, during his visit to the Philippines, described the earthquakes in this manner: «The destructive ravages and changes produced by earthquakes are nowhere more remarkable than in the Philippines. They have overturned mountains, they have filled up valleys, they have desolated extensive plains; they have opened passages for the sea into the interior and from the lakes into the sea». ${ }^{3}$ Prominent Filipino propagandist Graciano López Jaena considers earthquakes as a tempest and a «revolution of nature» that both devastate and nourish the islands. ${ }^{4}$ One can argue that these kinds of «at awe» observations in the country are typical and ordinary. But do these observations reflect the general sentiment of the concerned public?

The two major earthquakes in Luzon during the second half of the $19^{\text {th }}$ century, namely the June 1863 and the July 1880 earthquakes, present us an image of Philippine society in distress and shock, and reactive and decisive, in terms of responding to the needs of devastated by major terrestrial tremors. These earthquakes destructed Manila and neighboring provinces in the island of Luzon, and the scenarios after showed different responses from the Filipinos and the Spanish colonial government. The government focused on the political and economic measures, ${ }^{5}$ as well as on the engineering and technological aspects. ${ }^{6}$

As I argue, various strands of perceptions-religious, bureaucratic, and scientific, dominated the framework of response of the different sectors of the colonial state. The government and the influential hierarchy of the church had their own mechanisms on how they dealt with the perils of the disaster, and how they lifted the devastated cities and towns from the debris of the calamity. Each sector had its fair share of interpretations and making sense of the earthquakes-whether the earthquakes being geological phenomena, or a form of suffering caused by an angry God. On the one hand, visible were the predominance of religious explanations of the calamities. On the other hand, one development in this century was the surge of scientific research and use of instrumental in understan-

3. Bowring, Sir John, A Visit to the Philippine Islands, London, Smith, Elder \& Co., 1859, p. 81.

4. López Jaena, Graciano, «Discurso pronunciado por D. Graciano López Jaena el 25 de Febrero 1889 en el Ateneo Barcelonés», Guadalupe Fores-Ganzon, trans., La Solidaridad, vol. 1, 1889, Pasig City, Fundación Santiago, 1996, p. 22.

5. María Ramírez Martín, Susana, El terremoto de Manila de 1863: medidas políticas y económicas, Madrid, Consejo Superior de Investigaciones Científicas, 2006. Geaologo, Francis, «Historical Seismology and the Documentation of Postdisaster Conditions», Philippine Studies: Historical and Ethnographic Viewpoints 64:3-4, 2016, pp. 377-380.

6. Anduaga, Aitor, «Earthquake Building Overseas: Military Engineers, Cyclonic-Seismic Affinity and the Spanish Dominion in the Philippines, 1860-1898», Engineering Studies, 6:1, 2014, pp. 1-22. Anduaga, Aitor, Cyclones and Earthquakes: the Jesuits, Prediction, Trade, E Spanish Dominion in Cuba E the Philippines, $1850-$ 1898, Quezon City, Ateneo de Manila University Press, 2017. 
ding of environmental processes and events; military engineers, and later on, scientists and civil engineers, played vital roles in intellectualizing the cause, effect, and response mechanism of the state in dealing with earthquake threats. The default understanding of calamities was religious, yet scientific inquiries offered as an alternative for people to understand earthquakes as a common natural event.

\section{The devastation caused by the June 1863 and July 1880 earthquakes}

\section{The June 1863 earthquake}

On the evening of 3 June 1863, an earthquake struck in Luzon, damaging major urban centers in the island; specifically, it Manila and its adjacent provinces. The said earthquake made the capital city into a «pitiful tomb». ${ }^{7}$ The earthquake happened 7:30 in the evening, Wednesday, a day before the Feast of the Body of Christ (Corpus Christi). ${ }^{8}$ Selga describes the earthquake as a series of strong tremors, followed by upward and southward oscillation that was felt in Manila, the capital, the city suburbs, and towns outside the city. The quake destructed all the symbols of Manila's progress. ${ }^{9}$ A review article published in the Diario de Manila on December 1879 reports that the city was in grief; Manila was crying not only because of the death of her sons buried in the tormented edifices but also because that if they survive the catastrophe, they cannot endure the suffering of the tormented populace. ${ }^{10}$ An estimated 1,172 buildings were affected by the earthquake: 46 government and public buildings turned into ruins, including the palace of the Governor-General, the Audiencia Real, the barracks, warehouses, and commercial buildings, and churches, except the San Agustin Church; 25 other public buildings were severely damaged, and 570 private buildings were destroyed. ${ }^{11}$ The number of people killed reached almost 400, and injured were 2,000 individuals. ${ }^{12}$

The earthquake that lasted for only half a minute caused the Spanish capital major infrastructures to ravage and incalculable loss, both state and privately owned, and left

7. Selga, Miguel, «El Horrendo Terremoto del 3 de junio de 1863 en el Arzobispado de Manila», SEL S2.2 056, Personnel Data Records, Manila Observatory Library and Archives (MOLA), p. 1.

8. Selga, Miguel, La Relación Oficial del Terremoto del 4 de Junio de 1863 en Manila, Manila, Bureau of Printing, 1941, p.3.

9. Diario de Manila, 14 December 1879, cited by Selga, «El horrendo terremoto...», cit., p. 1.

10. Cited text: «Todo símbolo de progreso barrido por el desastre: Manila no lloró solo entonces la muerte de muchos de sus hijos sepultados entre los escombros de sus moradas y que, si sobrevivian algún momento a aquella general hecatombe, era para atormentar el ánimo de los vivos con la impotencia de todo auxilio», Diario de Manila, 14 de diciembre de 1879, cited by Selga, «El Horrendo terremoto...», cit., p. 1.

11. Saderra Masó, Miguel, Catalogue of Violent and Destructive Earthquakes in the Philippines, 1599-1909, Manila, Bureau of Printing, 1910, p. 13. The account of Manuel Peralta shows the same observation: Peralta, D. Manuel, «Relación del terremoto ocurrido en Manila el 3 de junio de 1863 especialmente en la catedral, leída ante el Sr. Arzobispo y clero catedralicio», EAR S1 072, Earthquake Data Records (MOLA), pp. 1-2.

12. Saderra Masó, Miguel, Catalogue of Violent and Destructive Earthquakes in the Philippines..., cit., p. 13. 
hundreds of dead bodies. ${ }^{13}$ In her study, Ramirez Martin considered this earthquake as the most catastrophic in terms of effects: the number of people that perished, the mobilization of public opinion towards Manila, and the difficulty of obtaining materials for reconstructions due to lack of funds and complex bureaucracy of the civil government. ${ }^{14}$ Going into refuge was the majority's first reaction, and then pain and dejection followed as many have witnessed the extent of the disaster. ${ }^{15}$ Almost all social groups in the city were affected by the disaster: officials, military personnel, business owners, the indigenous population, as well as the Chinese. ${ }^{16}$ The Illustrated London News reported that most of the victims were natives (Indians) and Chinese (Chinamen). ${ }^{17}$ Many people became casualties because of the earthquake hit the city during its rush hour, and it affected most of the residential areas beyond Manila's center. Most of the deaths and injuries were registered in highly dense urban areas, mostly with edifices and public structures. ${ }^{18}$ Selga notes that the «indígenas» made provisions at the time the earthquake struck, and some of the areas where structures damaged by the earthquake, particularly the markets, were also their house or habitation. ${ }^{19}$ Generally, the earthquake affected an approximate of $0.6 \%$ of the Philippine population at that time. ${ }^{20}$

\section{The July 1880 earthquake}

Almost two decades later, another devastating earthquake hampered Manila. Luzon Island frequently had experienced tremors in different provinces since 1863. On 18 and 20 July 1880, a major seismic movement was felt in Manila and its nearby provinces. It was described as «violent, vertiginous, and destructive». ${ }^{21}$ The tremors of the earthquake reached hundreds of kilometers from Manila up to the northern, southern, and southwestern parts of Luzon. Manila was the most ravaged amongst places, but the earthquake also caused immense destruction to towns in the provinces contiguous to the capital, in central and southern Luzon, such as Morong, Bulacan, Bataan, Pampanga, Tarlac, Nueva Ecija, and Pangasinan..$^{22}$ Manila, again, suffered significant losses in its urban infrastruc-

13. Selga, Miguel, El temblor de 1863 y las actas del Ayuntamiento de Manila, Manila, Bureau of Printing, 1941, p. 4.

14. Ramírez Martín, El terremoto de Manila de 1863..., cit., pp. 11-12.

15. Ibidem, p. 35.

16. Ibidem, pp. 25-27.

17. «The Earthquake at Manila», The Illustrated London News, p. 213, from Lietz, Rudolph J. H., The Philippines in the 19 $9^{\text {th }}$ Century: A collection of prints, Mandaluyong, RLI Gallery Systems, Inc., 1998.

18. Ramírez Martín, El terremoto de Manila de 1863..., cit., pp. 28-29.

19. Selga, La relación oficial del terremoto del 4 de junio de 1863 ..., cit., p. 4.

20. Ramírez Martín, El terremoto de Manila de $1863 \ldots$, cit., p. 32.

21. Saderra Masó, Miguel, La Sismología de Filipinas: datos para el estudio de terremotos del Archipiélago, Manila, Establecimiento Tipo-Litográfico de Ramírez y Compañía, 1895, p. 69; Anduaga, Aitor, «Earthquake Building Overseas...», cit., p. 7.

22. Saderra Masó, La Sismología de Filipinas..., cit., p. 24. 
tures, from government buildings to private properties; fissures and geographic displacements were seen in territories surrounding the capital region. ${ }^{23}$ Extreme physical destruction and communal grief were seen in affected areas. The days of continuous tremors put into shambles the decades of urban reconstruction of Manila and the «orderly completion of potential progress of this unfortunate land». ${ }^{24}$ The July 1880 earthquake in Manila and its adjacent provinces was instantly considered as a manifestation of God's hostility, and «the research of man hasn't touched it». ${ }^{25}$

Governor General Miguel Primo de Rivera described the disaster on that day as a result of almost five days of earth tremors; the quake killed dozens of people in cities and towns, it ruined public buildings and destroyed churches, and caused the collapse of some the military facilities. ${ }^{26}$ On 20 July 1880, two major aftershocks were felt in the city, more than and less than a minute long, that resulted to 9 deaths and 11 wounded, and two deaths and 50 wounded (mostly Chinese and natives), respectively. ${ }^{27} \mathrm{~A}$ third earthquake was felt on 22 July 1880 late evening and lasted for almost a minute. ${ }^{28}$ After several days of tremor, «tranquilidad» was experienced in Manila a week after the three days of tremors; ${ }^{29}$ and this was the time that civil government was able to communicate and compile all the local reports from the provinces affected by the earthquake. Outside the province of Manila, reports confirmed the severe damages to public infrastructures. Several of the towns in the province of Cavite, including the Fuerza San Felipe Neri, as well as the city proper, were severely damaged by the series of tremors that hit the island of Luzon. Twelve other provinces in the southern and northern regions suffered heavily after the quake. ${ }^{30}$

The two earthquakes caused huge infrastructural, economic, and human loses. The capital city was destroyed heavily twice, as its major buildings and churches collapsed, commercial and trade activities were paralyzed, and the people were in grief. Authorities

\section{Ibidem.}

24. Saderra Masó, Miguel, Historia del Observatorio de Manila, fundado y dirigido por las Padres de la Compañia de Jesús de Filipinas, 1865-1915, Manila, E. C. McCullough \& Co., Inc., 1915, p. 45.

25. Saderra Masó, Miguel, Historia del Observatorio de Manila..., cit., p. 45.

26. Archivo Histórico Nacional (AHN), Ultramar, 471, Exp. 1, «Telegram of the Governor General to the Ministers of War and Overseas, 18 July 1880», Terremotos que han tenido lugar en la isla de Luzón en los días 18 y 20 de julio de 1880 .

27. AHN, Ultramar, 471 Exp. 1, «Telegram of the Governor General to the Overseas Minister, 20 July 1880» (Documents n. ${ }^{\circ} 6$ and 7), Terremotos que han tenido lugar en la isla de Luzón en los días 18 y 20 de julio de 1880 .

28. AHN, Ultramar, 471 Exp. 1, «Telegram of the Governor General to the Overseas Minister, 22 July 1880», Terremotos que han tenido lugar en la isla de Luzón en los días 18 y 20 de julio de 1880.

29. AHN, Ultramar, 471 Exp. 1, «Telegram of the Governor General to the Overseas Minister, 27 July 1880», Terremotos que han tenido lugar en la isla de Luzón en los días 18 y 20 de julio de 1880.

30. AHN, Ultramar, 471 Exp. 1, Reports from Provincial Chiefs, Terremotos que han tenido lugar en la isla de Luzón en los días 18 y 20 de julio de 1880. «Relación del Alcalde Mayor de Nueva Ecija sobre los destrozos causados por los terremotos», EAR S1 071, Earthquake Data Records, MOLA. «Acta del reconocimiento verificado en los edificios públicos de esta capital con expresión de la seguridad que ofrecen y reparaciones más urgentes que se necesitan», «Desperfectos causados en los edificios públicos de la capital de Batangas por los terremotos de 1880», EAR S1 017, Earthquake Data Records, MOLA. 
acted on to provide relief and mitigation measures; these actions manifested the bureaucratic and religious nature of how the people and the government perceived earthquakes as a hazard and disaster. The «triumvirate» response of dealing with the bureaucratic complexities of the civil government, the religious actions of the Church, and the mobilization of scientific experts governed the rehabilitation and mitigation mechanisms implemented.

\section{Religious Interpretation and Responses}

Religious response is a reactive, yet constant and culturally lingering approach in dealing with disasters. As this kind is the most common amongst societies that experience widescale calamities, associating disasters with as a result of a benevolent or powerful being's scourge to the believer is a typical and expected response. In the Catholic pantheon, one saint is prayed for the salvation of people from earthquakes. In Italy, Spain, Mexico, and Cuba, San Emigdio (279-303/309 CE) is recognized as the patron or abogado (defender) against earthquakes, the roots of his veneration originates from Italy, in Ascoli Piceno, where he served as a Christian bishop and is credited for «saving» the said Italian city from an earthquake in $1703 .{ }^{31}$ His feast day is every $5^{\text {th }}$ of August of the Catholic year. ${ }^{32}$ There is no documentary evidence that proves that San Emigdio was widely prayed for during calamities. Bankoff argues due to the interaction between indigenous and JudeoChristian tradition, and there is an apparent duality in viewing the environment as both divine and fatal. ${ }^{33}$ Guided by the Church, people's reactions and response to the two earthquakes fell into this binary of benevolence-malevolence.

\section{The 1863 earthquake and the Secularization movement}

The destruction caused by the June 1863 earthquake was so extensive that many people, including the authorities, looked for answers beyond the rationale of the human realm. The earthquake was the triumph of death, ${ }^{34}$ and «agony and screams haunted the stillness of the night $\gg .^{35}$

Prayers and other religious activities followed the days of mourning and collective suffering. Some sectors of turned to be political to make sense of the situation. One im-

31. «San Emigdio, obispo mártir», <https://bit.ly/2QbbYdi>.

32. Torras, Vicente, Gozos al glorioso San Emigdio, Obispo y Mártir: abogado contra terremotos, su fiesta celebra la Iglesia el día 5 de agosto (Gracia, Barcelona, Imp. De Torras, 1879-1900). Biblioteca Digital Hispánica, Biblioteca Nacional de España (BNE).

33. Bankoff, Greg, «In the Eye of Storm...», cit., p. 95.

34. Peralta, «Relación del terremoto ocurrido en Manila el 3 de Junio de 1863 especialmente...», cit., pp. 9-10.

35. Selga, Miguel, «El horrendo terremoto del 3 de junio de 1863 en el Arzobispado de Manila», SEL S2.2 056, Personal Data Records, MOLA, p. 1. 
plication of the 1863 earthquake transcended up to the rivalry between the secular and regular priests. One sector that was put to blame by their political nemesis was the secular priests. It became one crucial turning point in the history of a social movement in the Philippines, the «secularization movement». During the June 1863 earthquake, Father Pedro Peláez, together with some members of the Cabildo Eclesiástico of Manila, was inside the cathedral as they were attending the solemn vespers of the feast of Corpus Christi. ${ }^{36}$ He died when debris fell into them. Fourteen members of the Cabildo survived the incident inside the cathedral, including Peláez's protégée, the young and intelligent mestizo priest from Vigan, Jose Burgos. ${ }^{37}$ Peláez, a diocesan administrator of the Archbishop of Manila, a professor of philosophy at the Colegio de San Juan de Letrán and the Universidad de Santo Tomas, was one of the recognized leaders of the secular priests. ${ }^{38}$ The friars attributed the death of Peláez to God's wrath over the seculars who were «demanding» so many reforms. Providential was what a writer of an article that appeared in the newspaper La Verdad shortly after the incident; the writer said that the earthquake frustrated the «armed rebellion» under Peláez leadership. ${ }^{39}$ Those who didn't dare to criticize Peláez took advantage of his death by censuring him publicly and publicizing of types of unjustified accusations. ${ }^{40}$ Moreover, Aguilar argues that the 1863 earthquake and its impact on the Secularization movement transcended two decades later, in the infamous speech by José Rizal in a brindis in $1884^{41}$ to honor fellow ilustrados who were victorious at the Exposición de Bellas Artes in Madrid.

\section{The Processions and Prayers after the two earthquakes}

The offering of prayers from different ecclesiastical districts and organization outside Manila, sharing and sending of resources to the capital, and improvised acts of individuals and civil organization were some of the immediate response to the call to help the affected communities of the earthquake. The Archbishop of Manila Pedro Payo y Piñiero asked parishes and parishioners to sing Te Deum to pray the Divine Mercy to protect the people not only from the affected provinces but also for the whole archipelago, and every prelate to lead the legion in praying for the souls of the victims, as well as their fa-

36. Blanco, Roberto, «Pedro Peláez: Leader of the Filipino Clergy», Philippine Studies, 58:1-2, Festschrift in honor of Fr. John Schumacher, S.J., 2010, p. 31.

37. Archivo de Filipinas, Biblioteca Tomás Navarro Tomás Centro de Ciencias Humanas y Sociales-Consejo Superior de Investigaciones Científicas (AF-BTNT-CCHS-CSIC), Letter from Dean D. Manuel Peralta, Cabildo Eclesiástico of Manila, regarding their experience inside the Manila Cathedral, 1 October 1863, Leg. 10 (1863-1870), Rollo 7421,

38. Blanco, «Pedro Peláez: Leader of the Filipino Clergy...», cit., pp. 4-11.

39. Schumacher, John, Revolutionary Clergy: The Filipino Clergy and the Nationalist Movement, 18501903, Quezon City, Ateneo de Manila University Press, 1998, p. 11.

40. Ibidem.

41. Aguilar, Filomeno, «Romancing Tropicality: Ilustrado Portraits of the Climate in the Late Nineteenth Century», Philippine Studies: Historical and Ethnographic Viewpoints, 64:3-4, 2016, p. 430. 
milies. ${ }^{42}$ On 22 July 1880, he also celebrated a mass dedicated to the Santa Maria Magdalena, the patron of repentant sinners, in the open field of Bagumbayan outside Intramuros, where he encouraged believers to pray and sacrifice for the city and the victims of the earthquakes. ${ }^{43}$ On 12 September 1880, the Gaceta de Manila published a circular of the Archbishop declaring 12 December 1880 as a special day to remember the disastrous earthquake. ${ }^{44}$ The Te Deum was sung on that day for the victims of the earthquake, and the resurrection of the city; the Governor General, ordered the officials of the Army and the Compañía de Artillería to assist in the mass by sending the troop band, playing music and parading the official flags of the troops. ${ }^{45}$

A week after the earthquake, the Augustinian friars celebrated a holy mass in honor of the La Santísima Virgen de la Consolación for keeping the religious safe from the quake, their church, and the convent. ${ }^{46}$ Later on, they sang a solemn «Salve» and conducted a procession of the statue of the patron around Manila for the blessing and recovery of all the people affected by the earthquake. ${ }^{47}$ On 02 July 1880 , a group of religious celebrated a mass at the Colegio de Santa Isabel, for the victims of the earthquake, and for their unscratched convent. ${ }^{48}$ The Paulinian institutions in Manila dedicated the celebration of their founder's anniversary to the victims of the quake. ${ }^{49}$ Outside Manila on 14 December 1863 , the Bishop of the Diocese of Cebu issued a pastoral letter directed to the parish priests of the towns under the said diocese to participate in the government's efforts to gather funds and donations through a public subscription for the victims of the earthquake in Manila. ${ }^{50}$

Residents had to cope with safety personally at the immediate period after the earthquakes. ${ }^{51}$ The religious institutions in Manila provided spiritual relief and led religious activities as a manifestation of their adherence to the providential nature of the disaster,

42. Selga, Miguel, «El terremoto de Manila del 3 de junio de 1863», cited in Selga, M., Índice y breve resumen de documentos relativos al temblor de Manila del 3 de Junio de 1863, p. 8.

43. «Rogativa en el campo de Bagumbayan por razon de los terremotos», cited from «Los terremotos en Filipinas en julio de 1880», EAR S1 058, Earthquake Data Records, MOLA.

44. Gaceta de Manila, Año 20, n. ${ }^{\circ}$ 254, p. 1744, «Solemne Te Deum por haber cesado los terremotos», EAR S1 075, Earthquake Data Records, MOLA.

45. Gaceta de Manila, Año 20, n. ${ }^{\circ}$ 254, p. 1744, «Solemne Te Deum por haber cesado los terremotos», EAR S1 075.

46. «La comunidad de Padres Agustinos y los terremotos de 1880», EAR S1 034, Earthquake Data Records, MOLA.

47. «La comunidad de Padres Agustinos y los terremotos de 1880», EAR S1 034. MOLA.

48. «El Colegio de Santa Isabel y los terremotos de 1880», EAR S1 025, Earthquake Data Records,

49. «Carta del P. Superior de los Paules sobre los terremotos de 1880» and «Carta del Sor Tiburcia Ayanz a la Superiora General de las Hermanas de la Caridad», cited from «Breve Reseña de la labor realizada en estas islas por la doble familia de San Vicente de Paul», Annales de la Congregación de la Misión, t. XLV, pp. 601-603, EAR S1 010 and 012, Earthquake Data Records, MOLA.

50. «Sobre una suscripción para socorrer las necesidades de Manila causa de los daños del terremoto», Romero Madridejos, Benito, Pastorales y demás disposiciones circuladas a los párrocos de esta diócesis de Cebú por los Señores Obispos ó sus Vicarios Generales, t. I, Manila, Est. Tip. Del Colegio de Santo Tomas, 1885, p. 266.

51. AHN, Ultramar, 471, Exp. 1, Document n..$^{\circ} 21$, Terremotos que han tenido lugar en la isla de Luzón en los días 18 y 20 de julio de 1880 . 
and the message it tried to relay regarding faith and devotion of the people. Several days after the earthquake, the social climate immediately changed; the spirit of the public has gone up, and a collective tranquil sentiment was felt, probably a manifestation of satisfaction to the fast response of the authorities. ${ }^{52}$ Likewise, different sectors interpreted the quick action of the authority as a manifestation of the powerful and natural support of the monarchy. ${ }^{53}$ Meanwhile, Governor-General Primo de Rivera's message to the people of Manila on 22 July 1880 published in a Gaceta Extraordinaria reflects the religious and scientific treatment of the earthquake. He asked the people to pray for God's mercy, but at the same time, encouraged people to help in the scientific inquiry of this «fenomeno geológico». ${ }^{54}$ This is a clear proof of the transition to a scientific response to earthquakes from the point of view of the government. Although the scientific initiatives did not start only after the July 1880 earthquake, the formative plans and requisites were laid down decades before. The emergence of professionals as the leading sector in disaster response resulted in a more bureaucratic and scientific character of post-disaster response.

\section{Bureaucratic and Scientific Responses}

The June 1863 and July 1880 earthquakes posed a great challenge, as well as an opportunity, to the state authorities and the people to «modernize» Manila's civil structures and urban landscape. Although it is arguable that structural modernity in this period of the $19^{\text {th }}$ century hasn't been achieved, an attempt to realize this vision of Bourbon modernity was principal to the post-disaster priority programs implemented. Public opinion, communication exchanges between pertinent stakeholders, and ministerial actions taken by government authorities reflect the crafting of comprehensive plans and propositions to address the needed urban rehabilitation of Manila and its suburbs.

\section{The Junta de Autoridades in 1863 and 1880: Domestic administrative decisions}

The major challenges the Spanish civil government faced after the two earthquake disasters were: (1) how to immediately facilitate rescue operations and (2) to expedite specific reconstruction efforts for the government to have infrastructural capacity to operate. Manila was severely destructed, making it almost on ground zero. The capital was at the brink of urban comatose after the earthquakes, affecting the city physically, and its human component. Towns of adjacent provinces were also affected, making vital commercial and administrative functions paralyzed.

52. AHN, Ultramar, 471, Exp. 1, Document n. ${ }^{\circ}$ 27, Terremotos que han tenido lugar en la isla de Luzón en los días 18 y 20 de julio de 1880 .

53. Ibidem

54. «Alocución del Gobernador General», EAR S1 003, Earthquake Data Records, MOLA. 
The civil government created an ad hoc group of officials and experts, which would facilitate and monitors all plans to be approved and executed, called the Junta de Autoridades Superiores. Looking closely, the Junta was composed of officials from various civil, military, and ecclesiastical offices. ${ }^{55}$ Its multisectoral composition was aimed at making a comprehensive assessment of the situation of affected areas.

After the June 1863 earthquake, the first set of measures taken fall under public wellness and city welfare. On the one hand, the civil government had to restore daily life and order; and on the other hand, the authorities also needed to revive public service and the economy of Manila. ${ }^{56}$ Buildings and structures that posed hazards to the public were demolished, except for several private homes, which suffered slight damages. ${ }^{57}$ Military engineers and architects led the assessment of damages as well as initial construction activities. ${ }^{58}$ It took the civil government for almost three months, to thoroughly clean the city from debris and collapsed structures. The workers, mostly polistas, ${ }^{59}$ took on the heavy work of clearing the streets of the city to normalize commercial and public traffic, and goods and transportation. For the objective to centralize and make a comprehensive, long-term the rehabilitation of Manila and other affected towns, Governor General Rafael de Echagüe issued a circular on 08 June 1863, colloquially labeled in newspapers as the «Bando de $08 »$, to address specific immediate needs in the city's urban rehabilitation, as well as some concerns on the access to basic commodities and additional number of workers needed by the government. Provisional structures were built in safely identified zones; the construction of temporary shelters for military personnel and workers and locating suitable places where government offices can be housed commenced to bring back order and function in Manila. Some of these transient structures were made from light materials, caña and nipa in particular, or house already built out of these structures were repaired first..$^{60}$

The observed initial actions of the government and the people after the earthquake showed a better overall response. French explorer Alfred Marché lamented that this quick and improved disaster response of all sectors, particularly the government, a manifestation of «el noble corazón español» (noble Spanish heart). ${ }^{61}$

55. Selga, Miguel, La Relación Oficial del Terremoto del 4 de junio de 1863..., cit., p. 6.

56. Ramírez Martín, S. M., El terremoto de Manila de $1863 . .$, , cit., p. 78.

57. «Sobre el terremoto que ha sufrido Manila el día 3 del corriente», in García del Canto, Antonio, Los Terremotos de Manila: estudios históricos sobre grandes terremotos que han tenido lugar en el Archipiélago Filipino, desde su descubrimiento por Magallanes hasta el 3 de junio de 1865, Madrid, Imprenta de D. A. Santa Coloma, 1863, p. 30.

58. García del Canto, Antonio, Los Terremotos de Manila..., cit., p. 30. The Diario de Manila commended the Cuerpo de Ingenieros for in tirelessly working out to assess the overall situation in the city despite only having a handful of personnel. Diario de Manila, Año 14, n. ${ }^{\circ}$ 131, 10 June 1863, AHN, Ultramar, 5196, Exp. 9.

59. Term used to the local people who do the required (or forced) work for the government, paid by a certain amount accordingly, for a designated period in a year.

60. Ramírez Martín, Susana María, El terremoto de Manila de 1863 ..., cit., p. 50.

61. El explorador francés Marche y los terremotos de 1880, EAR S1 027, Earthquake Data Records, Manila Observatory Archives. 
When the July 1880 earthquake hit Manila, the civil government was in the middle of the preparations for the annual celebration in honor of the Spanish Queen's birthday-the Dias de la Reina. The necessity to focus on the recovery of the city prompted then Governor-General Fernando Primo de Rivera to suspend the celebrations, as it was deemed ironic to push through with the festivities despite the unfortunate state of the capital and its nearby provinces. ${ }^{62}$ On 29 July 1880 , the Junta de Autoridades convened and passed a resolution about the appropriate measures for the city's rehabilitation, as well as to mitigate the potential destruction of possible aftershocks. ${ }^{63}$ The junta facilitated the mobilization of the government's fiscal resources, crafting of reconstructions plans, importation and control of prices of construction goods, as well as public contribution program from the provinces. ${ }^{64} \mathrm{~A}$ series of decrees by the Governor General in August 1880 marked the implementation of a new urban construction system that focused on the capacity of structures to be earthquake resistant, covering ordinary to large structures.$^{65}$ Changes in edifice construction were immediately observed, particularly on the use of materials such as hydraulic concrete and brick, galvanized iron and flat tiles (instead of cane and nipa), and in strengthening structural components such as foundations, walls, floors, balconies, trusses, bridge pillars, and building locations. ${ }^{66}$ The government took a close watch over the implementation of this current building code and practices. These proactive actions on masonry regulations boosted the government's campaign against inferior practices in construction. ${ }^{67}$ But, similar to the June 1863 earthquake, the authorities also faced the problem of sufficiency of workers for their initial post-disaster rehabilitation activities. Military personnel and daily-wage workers composed the bulk of the workforce in Manila, and in Cavite, where the Spanish naval base is located. ${ }^{68}$

62. Gaceta de Manila, Año XX, n. ${ }^{\circ}$ 204, p. 1379, 24 July 1880, Suspensión de una recepción oficial, EAR S1 081, Earthquake Data Records, MOLA.

63. AHN, Ultramar, 471, Exp. 1, Document n..$^{\circ}$ 30, Terremotos que han tenido lugar en la isla de Luzón en los días 18 y 20 de julio de 1880.

64. AHN, Ultramar, 471, Exp. 1, «Acta from the Junta de Autoridades on 18 July 1880», Terremotos que ban tenido lugar en la isla de Luzón en los días 18 y 20 de julio de 1880. AHN, Ultramar, 471, Exp. 1, Document n. ${ }^{\circ} 30$, Terremotos que ban tenido lugar en la isla de Luzón en los días 18 y 20 de julio de 1880. Gaceta de Manila, Año XX, n. ${ }^{\circ} 205$, p. 1387, 25 July 1880, Prórroga del plazo de paro de contribuciones, EAR S1 060, Earthquake Data Records, MOLA.

65. Gaceta de Manila, Año XX, n. ${ }^{\circ}$ 231, p. 1575, 20 August 1880, Decreto sobre construcciones aseísmicas, EAR S1 015. Gaceta de Manila, Año XX, n. ${ }^{\circ} 235$, p. 1603, Aplicación de las reglas para la construcción aseísmica de edificios, EAR S1 004; Gaceta de Manila, Año XX, n. ${ }^{\circ}$ 238, p. 1627, 27 August 1880, Cumplimiento de las reglas de construcción seísmica de edificios, EAR S1 014. Gaceta de Manila, Año XX, n. ${ }^{\circ} 233$, p. 1591, 22 August 1880, Conservación de las reglas sobre construcción aseísmica y reparación de edificios, EAR S1 053, Earthquake Data Records, MOLA.

66. Anduaga, Aitor, «Earthquake Building Overseas...», cit., p. 9.

67. Ibidem, pp. 9-10.

68. AHN, Ultramar, 471, Exp. 1, Document n. ${ }^{\circ} 27$ and 28, Terremotos que han tenido lugar en la isla de Luzón en los días 18 y 20 de julio de 1880. Gaceta de Manila, Año XX, n. ${ }^{\circ}$ 203, p. 1371, 23 July 1880, Determinación del precio de los artículos de primera necesidad, EAR S1 018, Earthquake Data Records, MOLA. AFBTNT-CCHS-CSIC, Rollo 948_1880. 


\section{Madrid's actions after the 1863 earthquake: Significant ministerial decisions}

The June 1863 earthquake catastrophe, as Ramirez argues, showed that the monarchy was not prepared to respond to the needs of the Philippines, despite its absolutist nature of leadership. ${ }^{69}$ The apparent geographic isolation of the Philippines, ${ }^{70}$ and Spain, having political and economic challenges in the Iberian Peninsula due to attempts to be a stable state, the royal government showed ineptness and slow decision-making character during the first few weeks since the earthquake. Two decades later, the Madrid government took a better mechanism in dealing with the extent of the July 1880 earthquake, and their participation in the rebuilding of the destructed towns was seen in its relatively proactive support to the initiatives by the Spanish civil government in Manila.

\section{Human capital support}

The response of the Madrid government to the disaster that struck Manila was through providing resources, which can be categorized into three: human, financial, and «moral» resources. It was able to mobilize its resources to gather humanitarian aid for the Philippines, banking on patriotic calls to help their «hermanos de ultramar». ${ }^{71}$ The government tapped institutions, both civil and ecclesiastical, to help assemble people and resources for the rehabilitation of Manila. The Madrid government sent technical experts who can help plan and erect buildings that are geologically and climatologically stable.

Rebuilding the urban glory of Manila and its nearby provinces required not only financial capital, but human and professional expertise as well. One of the outcomes of the 1863 earthquake was the influx of professional civil engineers (ingenieros coloniales) and architects. A series of royal orders from August to October 1863 was issued, encouraging people to help in the urban rehabilitation and reconstruction of infrastructures in Manila. ${ }^{72}$ This paved the way to the enlistment of specialists such as architects, industrial engineers, mechanics, carpenters, masons, locksmiths, and glassmakers, and plumbers. Hundreds, who were considered masters in their specific fields, were invited and volunteered. ${ }^{73}$ Governor General Echagüe welcomed the sending of these workers to Manila; although he stated that by October of 1863, they had achieved relative sufficiency in the number of baseline workers-local (indigenas) and Chinese (chinos operarios), despite the small salary they give. ${ }^{74}$

69. Ramírez Martín, S. M., El terremoto de Manila de 1863 ..., cit., p. 122.

70. Ibidem, p. 121.

71. Ibidem, p. 98.

72. AHN, Ultramar 5196, Exp. 5, Document n. ${ }^{\text {s }} 1$ and 2.

73. AHN, Ultramar 5196, Exp. 5, Documents 3-15, 19-103, 105-117.

74. AHN, Ultramar 5196, Exp. 5, Letter of Governor-General Echagüe to the Ministerio de Ultramar, 14 October 1863, Document n. ${ }^{\circ} 104$. 
As a supplement to the August 1863 degree, the royal government in Madrid release several decrees and orders to facilitate the sending and distribution of financial aid from Spain to the people of Manila. These decrees include a variety of relief procedures and monetary donation programs as a remedy to affected communities. These included personal monetary donations from the Queen, ${ }^{75}$ and subscription programs throughout Spain, and in the Caribbean colonies such as Cuba, Puerto Rico, and Santo Domingo. ${ }^{76}$ The 14-month subscription program ended on December 1864, and collected 39,110,677 reales and 10 cents. ${ }^{77}$ For Manila specifically, 20,756,439 pesos were collected from the subscription program, the donation of the Queen and the royal family, and certain private individuals. Only $26.33 \%$ of the total contributions were sent to Manila. The Church played a vital role in the fulfillment of this program: the clerics in Madrid convinced the people to donate for Manila, ${ }^{78}$ while the church authorities in Manila, who were part of the Junta Central de Socorros, were tasked in receiving donations, approving of beneficiaries, releasing of donations, and facilitating and accounting every financial transaction. ${ }^{79}$ The junta started the distribution of donations in July of 1865 , more than a year after the disaster. Most of the petitioners from Manila and nearby provinces lost their houses and properties or became widows or widowers, orphans, or injured people, which resulted in them being not able to work at all..$^{80}$ The subscription program solved two separate but coinciding concerns of the Madrid government. First, it streamlined the processing of donations, given the complicated nature of Spanish bureaucracy. And second, the economic support of the peninsula reinforced the economic dependence of Manila to Madrid, thus making the city closer at the heart of the empire's governance. ${ }^{81}$

\section{The role of the engineers and Jesuits scientists}

Since the second half of the 1860s, the government in Madrid and the civil government in Manila were looking for enhanced means of dealing with disasters and reconstruction. The destruction caused by hazards such as typhoons and earthquakes to infrastructures in the colonies were insurmountable and posed a heavy financial burden to the state.

75. AF-BTNT-CCHS-CSIC, Rollo 7421 Legajo 10 (1863-1870), Telegraphic communication with the Consul of Egypt on 09/17 August 1863.

76. Gaceta de Manila, Año 3, n. ${ }^{\text {s }}$ 224, 225, and 230, cited in Selga, Miguel, Índice y breve resumen de documentos relativos al temblor de Manila del 3 de junio de 1863, Manila, Bureau of Printing, 1941, pp. 9-10.

77. Ramírez Martín, S. M., El terremoto de Manila de 1863..., cit., p. 108.

78. Ibidem, pp. 100-104.

79. AF-BTNT-CCHS-CSIC, Rollo 7421 Legajo 10 (1863-1870).

80. Ibidem.

81. Ramírez Martín, S. M., El terremoto de Manila de 1863 ..., cit., pp. 100-104. 
They were able to mobilize the professional scientists, and civil and military engineers to make thorough studies about the relationship between natural hazards and human structures. Moreover, these specialists recommended approaches and mechanisms, and policies on how to efficiently address the problem and lay down the foundations of earthquake-resistant buildings in an earthquake-prone colony. These professionals played essential functions in knowledge production and in implementing programs on how to reconstruct communities, and how to mitigate the effects of hazards on public infrastructures. The studies they made were published and were available not only to the governments in Madrid at Manila but to aspiring engineers and practicing professionals in the field. Their works deal with aspects such as materials and methods in the construction of buildings.

The period between the two major earthquakes is a period for the Spanish colonial state to assess its knowledge of earthquakes, and readiness and preparedness in responding to crises caused by natural hazards. There was a collective thought that the earthquake experiences of 1863 and 1880 were to be understood using scientific norms, and the state was pushed to invest in mobilizing the scientific community for this endeavor. It is in this situation where Madrid stepped as a form of their direct support for the Philippines, much visible after the July 1880 earthquake. The production of knowledge was seen as multi-branched, semi-informal movement; two groups of professionals advanced the scientific research and studies about earthquakes: first were the Jesuits of the Observatorio Meteórologico de Manila (OMM), and the second was the Spanish colonial engineers-both from the military (ingenieros militares), civil (ingenieros coloniales) and of the mines (ingenieros de minas). One the one hand, the OMM started as a private institution; only after two decades of existence, in 1884, that the civil government in the Philippines absorbed it as a state agency. On the other hand, the band of engineers was mostly government employees, thus making their work a direct state initiative.

The government reinforced the presence of new groups of professionals to produce a scientific understanding of the earthquake and suggest technological solutions for the urban construction challenges posed by the earthquakes. The works of these professionals are the start of the emergence of modern and synergize seismology in the Philippines, manifested through scientific studies, commissioned works, and public scientific materials. But, scholarly opinions on this matter vary. In contrast, Alberto and Elena argue that the Madrid government paid little attention to the proactive scientific development, given the fact to the limited number of scientists and technologists who can be sent or were willing to be assigned in the Philippines. ${ }^{82}$ But clearly, there was a horde of scientists who traversed this ministerial undermining, and indeed placed themselves at the heart of knowledge production. The joint efforts of the military, mining, and civil engineers resulted in unshackling the restraints of earthquake science by reconstituting the

82. Elena, Alberto and Javier Ordonez, «Science, Technology and the Spanish Colonial Experience in the Nineteenth Century», Osiris, Volume 15, 2nd Series, 2000, p. 75. 
limits of their fields. ${ }^{83}$ The Jesuit scientists contributed to this scientific scheme by presenting up-to-date scientific studies on the nature of terrestrial movements, giving light to some issues regarding earthquakes and volcanic eruptions. The military engineers were hailed as «modern architects» of colonial infrastructure development, and their work marked the advancing of modern anti-seismic engineering in the Philippines ${ }^{84}$ while Jesuit scientists, spearheaded the instrumentation and institutionalization of physical sciences, such as seismology. ${ }^{85}$

\section{The Work of the Engineers}

Between the decades of 1860 and 1880, the military engineers of the Spanish civil government in the Philippines had two evident roles: they are part of the force assigned to clamp down and crush the remaining vestiges of the Muslim sultanates in Mindanao, and be the intelligentsia that took charge of inspecting, studying, planning, and executing plans for the reconstruction of buildings and edifices destroyed by the earthquakes, including Manila after the June 1863 disaster. ${ }^{86}$ Military engineers strengthened colonial fortifications in the archipelago and designed plans for constructing earthquake and cyclone-resistant buildings and structures. Lieutenant Coronel Gregorio Verdú, an engineer who served as naval command admiral from 1855 to 1864 , spearheaded a notable contemporary construction system..$^{87}$ The succeeding state engineers expanded the field of earthquake studies through applied researches, transforming theoretical ideas into actual policy schemes. The likes of Rafael Cerero Sáenz (1831-1906), José Centeno García (1841-?), Manuel Cortés (1839-1915), Antonio García del Canto (1823-1886), and Enrique Abella Casariego (?-1913) led the series of scientific studies pertaining to earthquakes. The works of Cortés and Cerero focused on earthquakes, earthquake engineering, and anti-seismic construction methods, while Abella, García del Canto, and Centeno contributed significantly in the production of scientific literature on seismology and geology.

Earthquake engineering programs spearheaded by the government's military engineers were tested not only in rebuilding Manila after 1863 but also after subsequent earthquakes, especially the July 1880 event. ${ }^{88}$ But another set of engineers, the mining engineers, was tapped to help in holistically understanding earthquake as a geological

83. Anduaga, Aitor, «Earthquake Building Overseas...», cit., p. 17.

84. Ibidem, p. 2.

85. Anduaga, Aitor, «Spanish Jesuits in the Philippines: Geophysical Research and Synergies between Science, Education, and Trade, 1865-1898», Annals of Science, 71:4, 2014. Álvarez, Kerby C., «Instrumentation and Institutionalization: Colonial Science and the Observatorio Meteórologico de Manila, 1865-1899», Philippine Studies: Historical and Ethnographic Viewpoints, 64:3-4, 2016.

86. Anduaga, Aitor, «Earthquake Building Overseas...», cit., pp. 3-7.

87. Ibidem, p. 5.

88. Ibidem, p. 7. 
phenomenon. Institutionalized in 1838, these experts were part of the Inspección General de Minas (IGM). Ordaz argues that the mining engineers formed part of the second (1841-1870) and third (1870-1898) stages of $19^{\text {th }}$-century geological knowledge production in the Philippines. ${ }^{89}$ On 29 July 1880, Governor General Primo de Rivera instructed the IGM to conduct a study about the earthquake, from the point of view of geology. ${ }^{90} \mathrm{It}$ has two main objectives: (1) to recommend a system of building houses, by identifying geological unstable and risky areas, and (2) to suggest possible modes of adaptation in towns and provinces affected by the earthquake. ${ }^{91}$ Looking closely, the instructions were also directed at surveying the effects of the July 1880 earthquake, and to provide a comprehensively scientific explanation of the phenomenon of an earthquake in the whole archipelago. The engineers sent reports about this experimental study to Madrid; one of which is the IGM chief engineer José Centeno's Memoria sobre los temblores de tierra ocurridos en julio de 1880 en la isla de Luzón. The Comisión de Mapa Geológica de España allotted parts of their scientific bulletin for the publication of the report of Centeno. ${ }^{92}$ From 1883 to 1884, the Comisión made Centeno's report a book published as a scientific output, and it produced and distributed copies of the study to different offices in Spain and Manila, as well as in Cuba and Puerto Rico.93

On 10 March 1866, a royal decree was issued creating the Inspección General de Obras Públicas (IGOP), aimed at institutionalizing public works as a state priority project. This decision to establish a new agency that will facilitate the modernization of public utilities and structures was influenced by a much more comprehensive report detailing the effects of the 1863 earthquake to Manila and its suburbs. ${ }^{94}$ More than a year after its establishment, on August 1867, the IGOP was tasked revisit the structural condition of the city, and to make a policy enhancement report on how to further improve the existing building code and public construction guidelines. ${ }^{95}$ Basically, it was an assessment of the efforts made in the past four years since the 1863 earthquake, and a study to enhance the work set by its predecessor committees created after the said earthquake. The existence of the IGOP as a separate institution somehow made the action on post-disaster rehabilitation planning more streamlined, especially after the July 1880 earthquake. «Progressive» policies, such as in urban construction, were concretely manifested at the end of the decade of the 1880s. These new policies were even featured in one of the is-

89. Ordaz, Jorge, «Datos acerca de los estudios geológicos realizados en filipinas en la época colonial», Llul, 20, 1997, pp. 177-180.

90. AHN, Ultramar 460, Exp. 44, Document n. ${ }^{\circ}$, Comisión del Ynspector de Minas para estudiar los temblores de tierra en los días 18 y 20 de julio de 1880.

91. AHN, Ultramar 460, Exp. 44, Documents n. ${ }^{\text {os }} 2$ and 4.

92. AHN, Ultramar 460, Exp. 44, Document n. ${ }^{\circ} 4$.

93. AHN, Ultramar 460, Exp. 44, Documents n. ${ }^{\text {s }} 12-1$.

94. For an extensive discussion of the institutional history of the Inspección General de Obras Públicas (IGOP), see Costelo, Ros, Construyendo la Colonia: La Inspección General de Obras Públicas de Filipinas, $1866-$ 1898. Trabajo Fin de Máster. Máster Interuniversitario en Historia Contemporánea, Universidad Complutense de Madrid, 2017.

95. AF-BTNT-CCHS-CSIC, Rollo 7421 Legajo 10 (1863-1870). 
sues of the Transactions of the Seismological Society of Japan in 1889, wherein it was identified as an example of the modern mechanism for aseismic buildings. ${ }^{96}$

The momentum of earthquake research was moving for decades directed by the engineers. The period in between the quakes was an opportune time to establish a better engineering science tradition; but as due to the social and political problems the archipelago faced in the last decade of the $19^{\text {th }}$ century, the efforts were halted and were shelved as mere scientific literature of the period. ${ }^{97}$

\section{The work of the Jesuits}

One concrete manifestation of the Jesuits' commitment to science was through the establishment of scientific agencies in different parts of the world. ${ }^{98}$ The establishment of the Observatorio de Manila in 1865, and the creation of its seismic department afterward provided another platform in understanding the scientific nature of Philippine earthquakes. One of the first seismologists in the country was Federico Faura (1840-1897), the first director of the observatory. His fellow Jesuits Fathers Juan Ricart (1838-1915), Miguel Saderra Masó (1865-1939), José Coronas (1871-1938), and William Repetti (1925-2014) were also active in pursuing researches in seismology in the late $19^{\text {th }}$ and early $20^{\text {th }}$ centuries.

The July 1880 earthquake tested Faura's scientific theories about earthquakes, as well as the initial work and studies made by the observatory as a scientific institution. The civil government called on Faura to inform civil engineers and local authorities of his observations, laying the foundation of his reputation and the observatory as a trustworthy institution. ${ }^{99}$ He served as the official informador of the Governor-General Primo de Rivera for the following ten days after 20 July $1880,{ }^{100}$ the latter putting to the former telegraph and other essential communication systems at his disposal. In a report submitted to the civil government by Faura, it contained the necessary information and initial scientific analyses about the tremors, such as exact duration and the nature and directionality of the tremors. ${ }^{101}$ In a separate report published in Gaceta Extraordinaria on 22 July 1880, Faura stated that as early as April and May 1880, and in the days before 18 July, they were able to record various movements in northern provinces of Luzon. ${ }^{102}$ Resounding was

96. «Building Regulations for Manila», Transactions of the Seismological Society of Japan, 14, Tokyo, Government Printing Office, 1889, 95-126.

97. Ibidem, p. 184.

98. Udías, Agustín, Searching the beavens and the earth: The history of Jesuit observatories, Dordrecht, Kluwer Academic Publishers, 2003. Udías, Agustín, «Jesuits' contribution to meteorology», Bulletin of the American Meteorological Society, 77: 2, 1996, pp. 2307-2315.

99. Anduaga, Aitor, «Earthquake Building Overseas...», cit., p. 8.

100. Saderra Masó, Miguel, La Seismología en Filipinas..., cit., pp. 46-48.

101. AHN, Ultramar 471, Exp. 1, Exp. 3, Document n. ${ }^{\circ} 21$, Terremotos que ban tenido lugar en la isla de Luzón en los días 18 y 20 de julio de 1880.

102. AHN, Ultramar, 5425 Exp. 26, n. ${ }^{\circ} 35$ 1-15, Resumen de observaciones seismométricas verificadas en 
Faura's work that colonial authorities and fellow scientists abroad were impressed. ${ }^{103}$ The civil authorities and the public received his observations as well; as an expression of the city's appreciation, the Manila council conferred upon him the title «Hijo Adoptivo de Manila». ${ }^{104}$

The Observatory's initial seismological work was highly regarded not only locally but by scientific communities abroad. Veteran seismologists in some relatively advanced countries were impressed by their work. ${ }^{105}$ Supervising the journal Boletin Seísmico placed them in the map of a progressive seismological research network, as they follow the Italian system in earthquake studies. ${ }^{106}$ The work of the observatory about the July 1880 earthquake, as well as in other environmental projects it started, propelled he realization for government officials to recommend it to become an official scientific agency under the civil government in the Philippines. In 1880, a commission was formed and supported the creation of a state meteorological and seismological service. ${ }^{107}$ After almost four years of submitting to the taxing bureaucratic structure in the Philippines and Spain, on 28 April 1884, the King of Spain issued a royal decree making the observatory the official meteorological and seismological service in the archipelago. ${ }^{108}$

State engineers and the Jesuit scientists of the observatory pursued separate studies about earthquakes, which indirectly led into a united effort and approach in assessing the scale and nature of damage of the recent earthquake. ${ }^{109}$ Indeed, they were tapped by the colonial government to look for scientific solutions to the problems of frequent terrestrial movements, as well as proposals on how to lessen the adverse effects of such environmental hazards. But the relationship between these two sectors did not go smoothly. Although many had commended the studies made by the observatory, some secular government officials had shown cold treatment to the work of the Jesuits. Saderra Masó told that there was an unpleasant incident between Faura and Centeno. ${ }^{110}$ The latter criticized the former for his apparent lack of involvement in the scientific interpretation of data, and the observatory's limited scope of work in the Manila area, which he thought was not enough to determine essential components of the Luzon-wide July 1880 earthquake. ${ }^{111}$ Between the two competing professionals-government engineers and Jesuits scientists, a form of «bureaucratic competition» emerged. The observatory's prominence somehow threated one of Centeno's visions. He had an intention to establish a Servicio Seismológico

el observatorio del Ateneo Municipal en los diversos temblores que tuvieron lugar desde el día 14 hasta el 25 de julio de 1880.

103. Anduaga, Aitor, «Earthquake Building Overseas...», cit., p. 8.

104. Saderra Masó, Miguel, Historia del Observatorio de Manila..., cit., William Repetti, «The Manila Observatory, Manila, Philippine Islands», The Woodstock Letters, 57:1, 1948, p. 7.

105. Anduaga, Aitor, «Spanish Jesuits in the Philippines...», cit., p. 514.

106. Ibidem.

107. Saderra Masó, Miguel, Historia del Observatorio de Manila..., cit., p. 74.

108. Ibidem, pp. 73-80.

109. Ibidem, pp. 7-8.

110. Ibidem, p. 49.

111. Anduaga, Aitor, «Earthquake Building Overseas...», cit., p. 8. 
de Filipinas, the same as with those in Italy, Japan, Switzerland, Portugal, and Germany, by purchasing equipment abroad. ${ }^{112}$ Moreover, his apparent animosity towards Faura was probably beyond science. Centeno, together with other officials of the civil government in the Philippines, was a mason. He was said to be a life-long Republican and head of the Spanish Masons in the Philippines. ${ }^{113}$ One may suspect that their politics coincided with how they treat each other's scientific ideas and studies.

\section{Conclusion}

The June 1863 and July 1880 earthquakes had lasting effects, beyond the insurmountable damage to public utilities and infrastructures. The two earthquakes, on the one hand, challenged the colonial government to implement changes concerning its urban development and engineering projects, and post-disaster response capabilities. On the other hand, the earthquake disasters provided avenues to involve modern scientific ideas in understanding environmental processes and stimulated a wave of policy reviews and scientific advancements on seismological research. Moreover, the two earthquakes made the people to unconsciously assess the role of hazards and disasters in their social and cultural life, through a bureaucratic reiteration to the overall mindset of the harmful effects of catastrophes to communities, through Catholic spirituality, documentation of calamities, and scientific research. One silver lining amongst all the responses and lapses after these disasters was the birth of intuitive improvisations along the lines of ministerial communications, which led to the broadening of spaces in which other proactive responses developed and took place. Whether it was systematically initiated or decided out of instinct, actions were made in the aim to create long-term solutions to the adverse effects of disasters. The institutionalization of scientific reforms was realized through the establishment of the IGOP in 1866, the OMM in 1884 with a functioning seismological department, and the expansive role of the IGM after the July 1880 earthquake. These agencies undertook extensive scientific research and made the production of empirical studies an indispensable aspect in colonial governance, not only for disaster-related events but also for long-term public use and development.

Lastly, quite far from the epicenter of disaster events are floating theoretical concepts such as nationalism. Despite its probable vagueness and disconnect to the visible situation, a nationalistic sentiment of belongingness and inclusion reinforced the notion of helping the disaster-stricken communities and making a safer society through modern science, a patriotic duty for several sectors of Spain's colonial entities. In various instances that people in the Iberian Peninsula regarded their concern and support to the Phi-

112. Saderra Masó, Miguel, Historia del Observatorio de Manila..., cit., p. 50.

113. Guerrero, Leon Ma., The First Filipino: A Biograpby of José Rizal, Manila, National Historical Commission, 1974, p. 178. 
lippines as a manifestation of «espiritu patriotico» ${ }^{14}$ (patriotic spirit), and their «love» to their insular brothers — «hermanos de ultramar» ${ }^{15}$ and «hermanos tagalos»—, ${ }^{116}$ to mention some. Certainly, disasters build broken notions of camaraderie and distant sentiments of inclusivity. But these rebuilding of connections were ephemeral. It did not last as in the decades until the end of the $19^{\text {th }}$ century, people saw another form for a battle for nationalist inclusion, led by the reformist students from the Philippines, and they brought the struggle from Manila to Madrid. ${ }^{117}$

\section{Sources}

Archivo de Filipinas, Biblioteca Tomás Navarro Tomás, Centro de Ciencias Humanas y SocialesConsejo Superior de Investigaciones Científicas (AF-BTNT-CCHS-CSIC), Rollo 7421, Legajo 10 (1863-1870).

AF-BTNT-CCHS-CSIC Rollo 948.

Archivo Histórico Nacional (AHN), ULTRAMAR 460, Expediente 44.

AHN, ULTRAMAR 471, Expediente 1.

AHN, ULTRAMAR 5196, Expediente 5.

AHN, ULTRAMAR 5196, Expediente 9.

AHN, ULTRAMAR 5245, Expediente 26.

Manila Observatory Library and Archives (MOLA), Data Records, EAR S1 003.

MOLA, Data Records, EAR S1 004.

MOLA, Data Records, EAR S1 010.

MOLA, Data Records, EAR S1 012.

MOLA, Data Records, EAR S1 014.

MOLA, Data Records, EAR S1 015.

MOLA, Data Records, EAR S1 017.

MOLA, Data Records, EAR S1 018.

MOLA, Data Records, EAR S1 025.

MOLA, Data Records, EAR S1 027.

MOLA, Data Records, EAR S1 034.

MOLA, Data Records, EAR S1 053.

MOLA, Data Records, EAR S1 058.

MOLA, Data Records, EAR S1 060.

MOLA, Data Records, EAR S1 071.

MOLA, Data Records, EAR S1 072.

MOLA, Data Records, EAR S1 075.

114. AHN, Ultramar, 5196, Exp. 15, Letter from Fernando de Aguirre, 20 August 1863.

115. Ramírez Martín, Susana María, El terremoto de Manila de 1863 ..., cit., p. 96.

116. Selga, Miguel, «El terremoto de Manila del 3 de junio de 1863 en el Arzobispado de Manila», revista de la Sociedad Astronómica de España y América, tomo XV, p. 76, cited in Selga, Índice y breve resumen de documentos relativos al temblor de Manila del 3 de junio de $1863 \ldots$, cit., p. 7.

117. See Schumacher, John, The Propaganda Movement, 1880-1895: The Creation of Filipino Consciousness, the Making of a Revolution, Quezon City, Ateneo de Manila University, 1997. 
MOLA, Data Records, EAR S1 081.

MOLA, Institutional Data Records, SEL S2.2 056.

\section{Bibliographic References:}

Aguilar, Filomeno Jr. V., «Romancing Tropicality: Portraits of Climate in the Late Nineteenth Century», Philippine Studies: Historical and Ethnographic Viewpoints, 64:3-4, 2016, pp. 417-454.

Alvarez, Kerby C., «Instrumentation and Institutionalization: Colonial Science and the Observatorio Meteorológico de Manila, 1865-1899», Philippine Studies: Historical and Ethnographic Viewpoints, 64:3-4, 2016, pp. 359-384.

Anduaga, Aitor, «Earthquake Building Overseas: Military Engineers, Cyclonic-Seismic Affinity and the Spanish Dominion in the Philippines, 1860-1898», Engineering Studies, 6:1, 2014, pp. 1-22.

—, «Spanish Jesuits in the Philippines: Geophysical Research and Synergies between Science, Education and Trade, 1865-1898», Annals of Science, 71:4, 2014, pp. 497-521.

-, Cyclones E Earthquakes: The Jesuits, Prediction, Trade, E Spanish Dominion in Cuba E the Philippines, 1850-1898, Quezon City, Ateneo de Manila University Press, 2017.

Bankoff, Greg, «In the Eye of Storm: The Social Construction of the Forces of Nature and the Climatic and Seismic Construction of God in the Philippines», Journal of Southeast Asian Studies, 35:1, 2004, pp. 91-111.

Blanco, Roberto, «Pedro Peláez: Leader of the Filipino Clergy», Philippine Studies, 58:1-2, Festschrift in honor of Fr. John Schumacher, S.J., 2010, pp. 30-43.

Bowring, Sir John, A Visit to the Philippine Islands, London, Smith, Elder \& Co., 1859.

«Building Regulations for Manila», Transactions of the Seismological Society of Japan, 14, Tokyo, Government Printing Office, 1889, pp. 95-126.

Costelo, Ros, Construyendo la Colonia: La Inspección General de Obras Públicas de Filipinas, 18661898, Trabajo Fin de Master. Master Interuniversitario en Historia Contemporánea, Universidad Complutense de Madrid, 2017.

Elena, Alberto y Javier Ordonez, «Science, Technology and Spanish Colonial Experience in the Nineteenth Century, Osiris, 15:2, 2000, pp. 70-82.

García del Canto, Antonio, Los Terremotos de Manila: Estudios históricos sobre los grandes terremotos que han tenido lugar en el Archipiélago Filipino, desde su descubrimiento por Magallanes hasta el 3 de junio de 1863, Madrid, 1863.

Gealogo, Francis, «Historical Seismology and the Documentation of Postdisaster Conditions: The 1863-1880 Luzon Earthquakes», Philippine Studies: Historical and Ethnographic Viewpoints, 64:3-4, 2016, pp. 359-384.

Guerrero, Leon Ma., The First Filipino: A Biography of José Rizal, Manila, National Historical Commission, 1974.

Huetz de Lemps, Xavier, «Materiales Ligeros vs. Materiales Fuertes: The Conflict between Nipa Huts and Stone Buildings in the $19^{\text {th }}$-century Manila», in Ordoñez, Elmer (ed.), The Philippine Revolution and Beyond, vol. 1, Manila, Philippine Centennial Commission, National Commission for Culture and the Arts, 1998, pp. 160-172.

Jaena, Graciano López, «Discurso pronunciado por D. Graciano López Jaena el 25 de Febrero 1889 en el Ateneo Barcelonés», Fores-Ganzon Guadalupe, trans. La Solidaridad, vol. 1: 1889, Pasig City, Fundación Santiago, 1996. 
Lietz, Rudolph J. H., The Philippines in the $19^{\text {th }}$ Century: A collection of prints, Mandaluyong, RLI Gallery Systems, Inc., 1998.

Madridejos, Benito Romero, Pastorales y demás disposiciones circuladas a los párrocos de esta diócesis de Cebú por los Señores Obispos ó sus Vicarios Generales, Tomo I, Manila, Est. Tip. Del Colegio de Santo Tomas, 1885.

Ordaz, Jorge, «Datos acerca de los estudios geológicos realizados en filipinas en la época colonial, Llul, 20, 1997, pp. 177-180.

Ramírez Martín, Susana María, El Terremoto de Manila de 1863: Medidas políticas y económicas, Madrid, Consejo Superior de Investigaciones Científicas, 2006.

Repetti, William, The Manila Observatory, Manila, Philippines, The Woodstock Letters, vol. 57, Number 1, Washington D.C., 1948, pp. 7-34.

Saderra Masó, Miguel, La Seismología en Filipinas: Datos para el estudio de terremotos del Archipielago Filipino, Manila, Establecimiento Tipo-Lotográfico de Ramírez y Compañía, 1895.

-, Catalogue of Violent and Destructive Earthquakes in the Philippines (with an Appendix Earthquakes in the Marianas), 1599-1909, Manila, Bureau of Printing, 1910.

-, Historia del Observatorio de Manila, fundado y dirigido por los padres de la misión de la Compaña de Jesús de Filipinas, 1865-1915, Manila, E. C. McCullough \& Co., 1915.

«San Emigdio, obispo mártir», <https://bit.ly/2QbbYdi>, Date accessed: 31 October 2018.

Schumacher, John, The Propaganda Movement, 1880-1895: The Creation of Filipino Consciousness, the Making of a Revolution, Quezon City, Ateneo de Manila University, 1997.

-, Revolutionary Clergy: The Filipino Clergy and the Nationalist Movement, 1850-1903, Quezon City, Ateneo de Manila University Press, 1998.

Selga, Miguel, El temblor de 1863 y las actas del ayuntamiento de Manila, Manila, Bureau of Printing, 1941.

—, Índice y breve resumen de documentos relativos al temblor de Manila del 3 de Junio de 1863, Manila, Bureau of Printing, 1941.

—, La Relación Oficial del Terremoto del 4 de Junio de 1863 en Manila, Manila, Bureau of Printing, 1941.

Torras, Vicente, Gozos al glorioso San Emigdio, Obispo y Mártir: abogado contra terremotos, su fiesta celebra la Iglesia el día 5 de Agosto, Gracia, Barcelona, Imp. De Torras, 1879-1900.

Udías, Agustín, Searching the heavens and the earth: The history of Jesuit observatories, Dordrecht, Kluwer Academic Publishers, 2003.

-, «Jesuits' contribution to meteorology», Bulletin of the American Meteorological Society, 77:2, 1996, pp. 2307-2315. 